\title{
The state of conflicts today: Can humanitarian action adapt?
}

\author{
Claudia McGoldrick* \\ Claudia McGoldrick works as Special Adviser to the ICRC's \\ Presidency and Office of the Director General. Prior to joining \\ the ICRC in 2006, she worked as Senior Country Analyst for \\ the Norwegian Refugee Council and as Africa Director for the \\ Committee to Protect Journalists in New York. As a journalist \\ reporting for various international media outlets such as the \\ BBC, Reuters, The Economist and The Guardian, she worked \\ for several years in West Africa, Central Asia and the United \\ Kingdom.
}

\section{Abstract}

How do the dynamics of contemporary armed conflict shape, and constrain, humanitarian action? Is the international humanitarian "system" 1 really at breaking point, as is often claimed? Or will it adapt to the changing realities not just of warfare but of global geopolitical shifts - as it has done repeatedly in the past - and evolve into something different? By way of response, the first part of this article offers a snapshot of today's armed conflicts and other situations of violence, focusing initially on the trends and features apparent in the Syrian conflict-which has in many ways come to define twenty-first-century warfare-and moving on to other countries and regions, many of which share at least some of these features, albeit in varying degrees. It considers the humanitarian consequences of today's armed conflicts and other situations of violence, and the implications for humanitarian response - which, at least on an international level, is indeed facing a watershed. The second part aims to show that even a glance back at key aspects of the evolution of humanitarian action over the past century-largely in response

* This article was written in a personal capacity and does not necessarily reflect the views of the ICRC. 
to the evolving nature of warfare and the developing international system-will remind us of quite radical changes in the face of major upheavals and challenges, not all of them dissimilar to those of today. The third part suggests that in today's global environment, international humanitarian response will continue to evolve and ultimately take on a different shape: one that reflects the changing nature of conflict and the geopolitical power shifts that go with it. With the rise of the global South, and the increasing recognition of the importance of local actors to humanitarian action, particular attention is given to the evolving relationship between local and international actors. In conclusion, the article reiterates some of the main reasons why humanitarian action-and international humanitarian actors in particular - will likely continue to adapt (albeit with varying degrees of success) to a changing world.

Keywords: armed conflict, humanitarian action, adapt, trends.

\section{A snapshot of contemporary conflicts}

\section{Trends and features of today's conflicts: Syria and beyond}

The armed conflict in Syria - from its beginnings in anti-government protests in March 2011 to its descent into a brutal war drawing in regional and world powers - has in many ways become emblematic of the state of conflicts today and of the challenges facing humanitarian action, encapsulating many of the key trends and features of both. As such, while it is just one of numerous internecine conflicts around the world causing immeasurable suffering, it does warrant special focus.

If one considers who is fighting the Syrian war, how it is being fought, and what for $^{2}-$ as well the catastrophic impact on the civilian population - one can quickly appreciate why it has been widely labelled as the most complex conflict of this century so far.

1 As noted by John Borton in Future of the Humanitarian System: Impacts of Internal Changes, Feinstein International Center, Somerville, MA, November 2009, a striking feature of the "humanitarian system" is the lack of clarity on what precisely it consists of and where the boundaries lie. There is no universal definition: some writers preface the term with "international" to distinguish it from national and local elements within affected countries, while some reject the use of the word "system" altogether on the grounds that it implies actors oriented towards common goals. See also Hugo Slim, "Global Welfare: A Realistic Expectation for the International System?", ALNAP Review of Humanitarian Action, Vol. 6, 2006, where Slim defines the "formal international humanitarian system" as "the mainly Westernfunded humanitarian system which works closely within or in coordination with the international authority of the United Nations and Red Cross movements".

2 See Martin Van Creveld, On Future War, Brassey's, London, 2001. The author develops what he calls a "non-trinitarian" theory of warfare, based on five key issues. He contrasts this with Carl von Clausewitz's classic "trinity" of the people, the government and the army. 
The parties to the conflict have become a myriad of shifting alliances on many levels, fighting on multiple fronts, with diverse and often opaque motivations for doing so. What began with unarmed protesters calling for President Assad's resignation - galvanized by the Arab Spring protests sweeping the region-steadily escalated into violent clashes between security forces and opposition supporters. This eventually spiralled into full-blown civil war as armed opposition groups and government forces battled each other for control of cities and strategic areas. The fighting evolved along increasingly sectarian lines, with Syria's Sunni majority pitted against Assad's Shi'a Alawite sect. Syria's neighbours were quickly drawn into a proxy conflict, with predominantly Shi'a States such as Iran and groups including Lebanon's Hezbollah supporting the government, and States such as Saudi Arabia, Turkey and Qatar supporting the Sunni-dominated opposition.

The proliferation of radical non-State armed groups, including jihadist groups such as Islamic State (IS), has added another dimension, with social media networks providing the main breeding ground for radicalization and recruitment of more and more mainly young people from around the world. ${ }^{3}$ IS has effectively been fighting a "war within a war" against the Al Nusra Front (affiliated to Al Qaeda) as well as against Kurdish and government forces. ${ }^{4}$ Adding to the overall chaos are unknown numbers of local militias with different patrons and fluid chains of command.

In September 2014, a multinational US-led coalition launched air strikes primarily against IS targets inside Syria, part of a "comprehensive and sustained counterterrorism strategy". ${ }^{5}$ One year later, in September 2015, Russia joined in the fray with its own military intervention aimed at relieving the pressure on President Assad's forces.

The methods and means of warfare used in the Syrian conflict are as diverse and multilayered as the actors employing them. Weaponry is just one aspect of this complexity. Just as the suffering of civilians in Syria had already reached unprecedented levels from the use of conventional weapons, large-scale use of chemical weapons in rural Damascus in August 2013 - in blatant violation of international humanitarian law (IHL) - killed hundreds of people and injured many more. ${ }^{6}$ Despite the subsequent destruction of Syria's chemical weapons arsenal, under a joint mission led by the United Nations (UN) and the Organization for the Prohibition of Chemical Weapons (OPCW), there have been continuing allegations of the use of toxic chemicals such as chlorine gas, and in

3 Jytte Klaussen, "Tweeting the Jihad: Social Media Networks of Western Foreign Fighters in Syria and Iraq", Studies in Conflict and Terrorism, Vol. 38, No. 1, 2015.

4 BBC News, "Guide to the Syrian Rebels", 13 December 2013, available at: www.bbc.com/news/worldmiddle-east-24403003 (all internet references were accessed in December 2015).

5 Barack Obama, "Statement by the President on ISIL", 10 September 2014, available at: www.whitehouse. gov/the-press-office/2014/09/10/statement-president-isil-1.

6 Statement by ICRC, "Toward the Complete Elimination of Chemical Weapons - Meeting of the Chemical Weapons Convention, 2013”, The Hague, 3 December 2013, available at: www.icrc.org/eng/resources/ documents/statement/2013/chemical-weapons-convention-states-parties.htm. 
some cases "compelling confirmation" that it was "systematically and repeatedly" used as a weapon. ${ }^{7}$

The conflict has seen the indiscriminate use of weapons - many of them heavy or highly explosive - in densely populated urban areas, with devastating humanitarian consequences for civilian populations. $^{8}$ Shelling and aerial bombardment, including the use of barrel bombs, have continued in defiance of a UN Security Council resolution ${ }^{9}$ in February 2014 demanding that they cease. There have also been reports of the use of cluster munitions, which by their very nature are indiscriminate and contrary to IHL. ${ }^{10}$ Indeed, key notions of IHL governing the conduct of hostilities - such as "military objective", the "principle of proportionality" and "precaution" - have been regularly disregarded in the Syrian conflict.

The use of remotely piloted aircraft (armed drones) in US-led air strikes in Syria has also been highly controversial (as it has been in other countries including Iraq, Yemen and Pakistan). ${ }^{11}$ Defenders of drone strikes insist that their relative precision greatly minimizes the risk of collateral damage, while critics argue that they can constitute extrajudicial killing and that hundreds of civilians have died in such strikes. While the use of armed drones is not per se illegal under IHL, once used in armed conflict they have to comply with principles of distinction, proportionality and precaution. ${ }^{12}$

Flagrant violations of IHL - including direct attacks against civilians and services such as hospitals and schools - have characterized the Syrian conflict and have been committed by various parties, mostly with impunity. In the case of groups such as IS, contempt for IHL appears deliberate and pronounced, with mass killings of captured fighters from rival armed groups and executions, including the beheading of hostages, glorified on social media and used for propaganda purposes.

The readiness of some armed groups to commit atrocities on foreign soil and the perception of these, in some cases, as "acts of war" - has added another layer of complexity. The legal frameworks governing terrorism and IHL are fundamentally different, with distinct rationales, objectives and structures. Crucially, in legal terms, certain acts of violence are considered lawful in armed conflict and others unlawful, whereas acts of violence designated as "terrorist" are

7 OPCW Fact-Finding Mission, “'Compelling Confirmation' that Chlorine Gas Used as a Weapon in Syria", 10 September 2014, available at: www.opcw.org/news/article/opcw-fact-finding-missioncompelling-confirmation-that-chlorine-gas-used-as-weapon-in-syria/.

8 UN, “"Running Out of Words' to Describe Horror in Syria, Senior United Nations Officials Tell Security Council, Calling for More Vigorous Action”, 25 February 2015, available at: www.un.org/press/en/2015/ sc11801.doc.htm.

9 UNSC Res. 2139, adopted 22 February 2014.

10 ICRC, "Cluster Munitions: Overview", 30 November 2011, available at: www.icrc.org/eng/war-and-law/ weapons/cluster-munitions/overview-cluster-munitions.htm.

11 Chris Cole, "The Dirty Consequences of Our Clean Wars", Drone Wars UK, 5 December 2014, available at: http://dronewars.net/2014/12/05/the-dirty-consequences-of-our-clean-wars/.

12 Jelena Pejic, "Extraterritorial Targeting by Means of Armed Drones: Some Legal Implications", ICRC, 7 May 2015, available at: www.icrc.org/en/document/jelena-pejic-extraterritorial-targeting-means-armeddrones-some-legal-implications. 
always unlawful. The blurring of terrorism and war - particularly prevalent after the 11 September 2001 attacks in the United States and resurging again more recently has tended to seriously undermine the construct of IHL, and to cause problems particularly when the term "terrorism" (or "acts of terrorism") is used for political ends. ${ }^{13}$

The rules of IHL governing humanitarian access to populations in need ${ }^{14}$ have likewise been routinely disregarded by the parties to the conflict, particularly in besieged areas, leaving millions of residents in desperate need of food, water and health services (see section "Challenges to Humanitarian Response", below). A series of 2014 UN Security Council resolutions calling, among other things, for sieges of populated areas to be lifted and authorizing cross-border UN aid operations without Syrian government consent were ultimately "ignored or undermined by the parties to the conflict, other UN member states, and even by members of the UNSC itself', according to a report signed by twenty-one humanitarian and human rights organizations. ${ }^{15}$

A divided UN Security Council and a general lack of international convergence is another characteristic feature of the Syrian conflict. Numerous attempts by the Arab League and the UN to broker ceasefires and initiate dialogue have invariably failed, with a political solution appearing as elusive as ever. Indeed, the failure of the international system more broadly to deal effectively with the causes and consequences of violent crises - that have in some cases engulfed entire regions - has placed an increasingly heavy burden on humanitarian organizations to protect and assist the people affected by them.

While the Syrian conflict may be particularly complex, its features are by no means atypical in today's global environment. Multiple protracted armed conflicts, often with regional repercussions, are typically characterized by complex webs of asymmetric warring parties, in particular fragmented and multiplying non-State armed groups (as well as by private military and security companies, urban gangs, militias and a broad range of transnational criminal entities, including "terrorist" groups); by a widespread lack of respect for even the most fundamental rules of IHL; and by a lack of any viable political solution to end them. Failing infrastructure and public services, chronic hardship and poverty, and displacement on a massive scale-reversing development gains previously made - are just some of the outcomes (see section "Humanitarian Consequences of Today's Conflicts", below). And globally, armed conflict and armed violence are increasingly concentrated in urban areas, with catastrophic humanitarian

13 32nd International Conference of the Red Cross and Red Crescent, Background Report on International Humanitarian Law and the Challenges of Contemporary Armed Conflict, 32IC/15/11, 2015, pp. 16-21, available at: http://rcrcconference.org/wp-content/uploads/sites/3/2015/10/32IC-Report-on-IHL-andchallenges-of-armed-conflicts.pdf.

14 See Peter Maurer, "IHL and Humanitarian Principles are Non-negotiable - Syria Is No Exception", 15 February 2014, available at: www.icrc.org/eng/resources/documents/article/editorial/2014-02-15-syriamaurer-humanitarian-principles.htm.

15 Martin Hartberg, Dominic Bowen and Daniel Gorevan, Failing Syria: Assessing the Impact of UN Security Council Resolutions in Protecting and Assisting Civilians in Syria, 12 March 2015, available at: www.oxfam. org/en/research/failing-syria. 
consequences. Some 50 million people living in urban areas today face protracted and repeated armed violence. ${ }^{16}$

On a regional level, Syria and Iraq are at the centre of spiralling chaos in the Middle East - a multidimensional battlefield of entangled and competing ideological and political interests at the local, regional and global levels. The fallout of the conflict-driven humanitarian crisis in Syria weighs heavily on its neighbours: Turkey, Lebanon, Jordan and Iraq are between them hosting over 4 million refugees fleeing the chaos. ${ }^{17}$

Yemen's deepening armed conflict has likewise pulled in numerous countries in the region. ${ }^{18}$ Months of heavy fighting and sustained air strikes have created a catastrophic humanitarian situation, with a mounting death toll and the basic means of survival running out for people already struggling to cope with the effects of recurrent upheaval, drought and chronic impoverishment. ${ }^{19}$ In the longest military occupation in modern times, heightened tensions saw a resurgence of violence in Israel and the Occupied Territories, with dozens of people killed in a spate of clashes in October 2015 alone. ${ }^{20}$ And in another development with significant implications for regional-and global-power politics and conflict dynamics, world powers finally reached a deal with Iran in July 2015 limiting Iran's nuclear activity in return for the lifting of sanctions. ${ }^{21}$

Elsewhere, armed conflict and armed violence similarly affect entire regions. The ongoing fighting in northeastern Nigeria, for example, is being felt throughout the Lake Chad region. While Nigeria itself is suffering the main impact of its army's fight against Boko Haram-a group as diffuse as it is radicalized - the conflict has spread beyond Nigeria's borders into neighbouring Chad, Cameroon and Niger, displacing more than 1.5 million people (mostly within Nigeria itself). ${ }^{22}$ Across the Sahel region, people continue to suffer the effects of armed conflict in northern Mali and in Libya, exacerbated by a severe food crisis and environmental pressures.

South Sudan, the Central African Republic, Somalia and the Democratic Republic of Congo (DRC) are mired in protracted armed conflicts (the latter with

16 ICRC, Urban Services during Protracted Armed Conflict: A Call for a Better Approach to Assisting Affected People, Geneva, October 2015, available at: www.icrc.org/en/document/urban-services-protractedconflict-report.

17 See UN Office for the Coordination of Humanitarian Affairs (OCHA), "Syrian Arab Republic", available at: www.unocha.org/syria.

18 Jeremy Shapiro, "Why Are 10 Countries Attacking Yemen?", Brookings, 26 March 2015, available at: www.brookings.edu/blogs/order-from-chaos/posts/2015/03/26-why-attack-yemen-shapiro.

19 ICRC, "Conflict in Yemen: Political Solution Needed to End the Suffering", 11 August 2015, available at: www.icrc.org/en/document/yemen-political-solution-needed.

20 Al Jazeera, "Mapping the Dead in Latest Israeli-Palestinian Violence", 24 November 2015, available at: www.aljazeera.com/indepth/interactive/2015/10/mapping-dead-latest-israeli-palestinian-violence151013142015577.html.

21 Julian Borger, "Iran Nuclear Deal: World Powers Reach Historic Agreement to Lift Sanctions", The Guardian, 14 July 2015, available at: www.theguardian.com/world/2015/jul/14/iran-nuclearprogramme-world-powers-historic-deal-lift-sanctions.

22 ICRC, "Nigeria: Massive Long-Term Effort Required to Tackle Humanitarian Crisis in the North", 21 May 2015, available at: www.icrc.org/en/document/nigeria-massive-long-term-effort-needed-tacklehumanitarian-crisis-north. 
repercussions throughout the Great Lakes Region). After decades of intermittent armed conflict in Afghanistan, in 2015 fighting intensified again and the overall numbers of civilian casualties were on the rise. And in Ukraine, even though a fragile ceasefire was holding in late 2015, the likelihood of protracted political and humanitarian crisis seems little diminished.

On a more optimistic note, towards the end of 2015 Colombia looked close to a historic peace agreement that would end more than fifty years of civil war - one of the world's longest ongoing armed conflicts, which has displaced millions and caused suffering on a huge scale. However, armed violence continues to be a serious problem in various urban areas, and threats, disappearances, sexual violence, mines and unexploded ordnance are continuing to take their toll on civilians in different parts of the country.

Indeed, elsewhere in Latin America, the phenomenon of armed violence much of it drug-related violent crime - continues to kill many thousands of people every year. According to the 2015 Global Burden of Armed Violence report (that serves the Geneva Declaration on Armed Violence and Development), the three most violent countries in the world (based on numbers of violent deaths in 2012) were Syria, Honduras and Venezuela. ${ }^{23}$

\section{Humanitarian consequences of today's conflicts}

\section{Casualties and displacement}

The number of armed conflicts around the world has been progressively declining in recent years, yet the number of fatalities appears to have increased dramatically (in 2008, a global total of sixty-three armed conflicts produced 56,000 fatalities, whereas in 2014 a global total of forty-two armed conflicts produced 180,000 fatalities, according to the International Institute for Strategic Studies (IISS)). ${ }^{24}$ Even with the caveats that the business of assessing numbers of war casualties is notoriously complex and often controversial, and that statistics should in many cases be treated with caution, ${ }^{25}$ there does seems to be a strong argument that armed conflicts have become more deadly over the last few years.

Beyond direct casualties, increased massive displacement across continents is one of the most visible consequences of today's armed conflicts and violence. By the end of 2014, worldwide displacement was at the highest level ever recorded, with a staggering 59.5 million people forcibly displaced. ${ }^{26}$ Syria has become the world's single-largest driver of displacement, and has alone made the Middle East the

23 Geneva Declaration on Armed Violence and Development, Global Burden of Violence 2015: Every Body Counts, Geneva, May 2015, available at: www.genevadeclaration.org/measurability/global-burden-ofarmed-violence/gbav-2015/press-release.html.

24 IISS, Armed Conflict Survey 2015, May 2015, available at: www.iiss.org/en/publications/acs/by\%20year/ armed-conflict-survey-2015-46e5.

25 Adam Roberts, "Lives and Statistics: Are 90\% of War Victims Civilians?", Survival, Vol. 52, No.3, 2010, pp. 115-136.

26 Office of the UN High Commissioner for Refugees (UNHCR), Global Trends 2014: World at War, Geneva, June 2015, available at: www.unhcr.org/558193896.html. 
biggest producer and host of displaced people. As of the end of October 2015, almost 4.2 million registered refugees from Syria were being hosted by neighbouring countries, and more than 6.6 million were internally displaced - in total around half of the pre-war population of 22 million. As of December 2015, the UN estimated that 13.5 million people were in need of humanitarian assistance inside Syria. ${ }^{27}$

The "migrant crisis" that began to unfold in Europe in 2015 - with hundreds of thousands of refugees, asylum seekers and other migrants arriving on European shores and borders, with the promise of many more to come - is just one part of this. The vast majority of the migrants making the perilous journey to Europe are fleeing the wars in Syria and Afghanistan, many having seen their homes and livelihoods destroyed and/or their loved ones killed or injured, and seeing no hope for a viable existence where they were. The levels of devastation inside Syria are such that, even if the fighting were to end, there may be few Syrians who see any realistic prospect of returning there in the near future.

Moreover, this is part of a much bigger picture: countless numbers of migrants living in - or crossing through - countries affected by armed conflict or violence in various parts particularly of Central America, the Sahel region of Africa, Southeast Asia and the Arabian Peninsula have in recent years risked their lives in search of safety and a better future for themselves and their families. Migration will clearly be a defining feature of the twenty-first century, with people fleeing armed conflict or violence, economic hardship, climate change, food scarcity or, increasingly, a combination of all of these.

\section{Impact on people's resilience}

There are different ways in which the characteristics of contemporary conflict or violence impact on people's vulnerabilities and needs, as well as on their resilience. In the first instance, there are those directly affected, with civilians in many cases deliberately targeted, often on religious, ethnic or sectarian grounds. As outlined above, in numerous contexts civilians are the main targets of systematic abuses of IHL and human rights by parties to conflict. In some cases they fall victim to the use of illegal weapons - such as chemical weapons or cluster munitions - or to indiscriminate bombardment of populated areas. Mines, explosive remnants of war and booby traps in some contexts pose a major threat to both resident and returning populations. Apart from the death and injury sustained, the destruction of property, livelihoods, vital infrastructure and services such as health-care facilities and schools - or simply the lack of access to them has a devastating effect with long-term repercussions.

Constrained access to emergency and basic health-care services in many situations of armed conflict and violence is of particular concern, caused by a widespread lack of respect for the rules of IHL related to the protected status of the medical mission, and seen in recurrent attacks on health-care staff and 
facilities. Egregious attacks such as the highly publicized one against the Médecins Sans Frontières (MSF) hospital in Kunduz, Afghanistan, in October 2015, are just one small part of a much bigger picture: the International Committee of the Red Cross (ICRC) documented almost 2,400 attacks against health care (personnel, facilities, transport and patients), by a range of perpetrators, in eleven countries over three years up to December 2014. ${ }^{28}$ The impact of such attacks cannot be overestimated: following the destruction of one of its hospitals in Yemen's Saada province in October 2015, MSF reported that at least 200,000 people were left without access to vital medical care. ${ }^{29}$ Close to 100 similar incidents were reported in Yemen alone between March and November 2015, according to the ICRC. ${ }^{30}$

Also directly affected by conflict or violence are persons deprived of their liberty in these settings. They are particularly vulnerable to torture and even summary executions in some cases, as well as cruel, inhuman or degrading treatment, be it physical and psychological ill-treatment or material conditions amounting to the same.

Other than those directly affected, many more people are affected by the cumulative, long-term effects of conflict or protracted situations of violencethere is a gradual breakdown of water, electricity and sanitation services, while collapsing infrastructure means that hospitals and health-care services can no longer care for the wounded or treat chronic diseases. ${ }^{31}$ This is exacerbated by the loss of employment and education opportunities, leading to situations of chronic poverty and hardship that make people less resilient to sudden shocks.

\section{Vulnerabilities of specific groups}

Then there are groups of people with specific vulnerabilities related to their gender and/or age, such as women, children and the elderly. The demographics of Europe's "migrant crisis" raise questions in this regard: of the almost 800,000 refugees, asylum seekers and other migrants who had arrived in Europe via the Mediterranean Sea between January and November 2015, women represented only $15 \%$ of the total, and children $23 \%$ (according to data from the Office of the UN High Commissioner for Refugees $(\mathrm{UNHCR})^{32}$ ), whereas the average percentages of women and children in refugee and migrant populations are generally much higher than this.

28 ICRC, Health Care in Danger: Violent Incidents Affecting the Delivery of Health Care (January 2012December 2014), Geneva, 2015, available at: www.icrc.org/eng/what-we-do/safeguarding-health-care/ index.jsp.

29 MSF, "Yemen: MSF Hospital Destroyed by Airstrikes", 27 October 2015, available at: www. doctorswithoutborders.org/article/yemen-msf-hospital-destroyed-airstrikes.

30 ICRC, "Yemen: Attacks on Health Care Facilities Must Stop", 10 November 2015, available at: www.icrc. org/en/document/yemen-attacks-health-care-facilities-must-stop.

31 ICRC, above note 16.

32 UNHCR, "Refugees/Migrants Emergency Response - Mediterranean”, available at: http://data.unhcr.org/ mediterranean/regional.php. 
There may be different reasons for this disparity. As the numbers of refugees fleeing places like Syria and Afghanistan have surged, there have undoubtedly been many women and children among those too weak and vulnerable to make the perilous journey that has already claimed thousands of lives. Protection needs remain acute during and after flight too, with women and children refugees and migrants particularly exposed to abuse and exploitation. The journey is also an expensive one to make (a fact exploited by traffickers): in some cases the men may leave first, hoping to be able to send for their families later. On the other hand, many other women may be staying behind because of their role and responsibilities as head of the household, looking after others who are unable to flee. Their strength and resilience are in many cases the lifeblood of their families and extended community networks. ${ }^{33}$

Clearly, war has always impacted men and women differently, with relatively few numbers of women participating directly in hostilities. Yet in contemporary armed conflicts - be they in Syria or Afghanistan, Yemen or the DRC - women and children increasingly suffer disproportionate harm (in 2008, a well-known UN force commander, having served in the eastern DRC, famously asserted that it is more dangerous to be a woman than to be a soldier in modern conflict $^{34}$ ).

In an alarming number of cases, women and girls are deliberately targeted as a tactic of warfare, subjected to horrific sexual violence and other injury, and vulnerable to trafficking and other forms of exploitation. They may also be left as the sole breadwinners of their households, with responsibility for supporting families on their own. In northeastern Nigeria, for example, the conflict has left many thousands of women widowed. With little or no formal education, many are unable to find work and have been reduced to begging, unable to provide for their children. In turn, huge numbers of children - many of them displaced have no opportunities to go to school and are likewise sent to beg or to do menial work at a very young age. In conflict-affected countries globally, a staggering 34 million children are estimated to be out of school. ${ }^{35}$

Children in armed conflicts are particularly vulnerable in a number of ways. Despite the protection provided by law, children are still being recruited by (or are otherwise associated with) national armed forces and by armed groups in various conflicts around the world - tens of thousands of boys and girls in more than

33 See, for example, UNHCR, United Nations Population Fund and Women's Refugee Commission, Initial Assessment Report: Protection Risks for Women and Girls in the European Refugee and Migrant Crisis Greece and the former Yugoslav Republic of Macedonia, 20 January 2016 (based on field assessments carried out in November 2015), available at: www.unhcr.org/569f8f419.html. See also Katharine Donato, The Invisibility of Today's Women Refugees, 3 November 2015 (with additional references), available at: https://thesocietypages.org/specials/the-invisibility-of-todays-women-refugees/.

34 Major General Patrick Cammaert, quoted in 2008 Parliamentary Hearing at the United Nations, New York, 20-21 November 2008.

35 Hayley Cull, "7 Ways the World is Failing to Keep Children Safe in Wars and Disasters", 5 November 2015, available at: http://blogs.unicef.org.uk/2015/11/05/how-the-world-is-failing-to-keep-children-safein-wars-and-disasters-in-7-shocking-statistics/. 
20 countries. ${ }^{36}$ Vulnerability particularly to recruitment and use by armed groups is seen to be increasing as conflicts are becoming "more brutal, intense and widespread". ${ }^{37}$ While in many situations children carry arms and actively take part in the fighting, they are also used in supporting roles such as messengers, porters and cooks, and for forced sexual services. Some are abducted or forcibly recruited, while others are driven by poverty, abuse or a desire for revenge. The likelihood of children becoming child soldiers is increased when they are already separated from their families, displaced from their homes, and given limited access to education.

\section{The invisible scars of war}

One of the most significant consequences of armed conflict and other situations of violence in general is the impact on the mental health and psychosocial well-being of the people affected. The psychosocial, psychological and psychiatric problems caused or exacerbated by conflict are of huge concern, even long after conflicts end. Those affected may include families of the missing in countries like Colombia and Nepal; victims of sexual violence in the DRC, South Sudan, the Central African Republic and Syria, to name but a few; other victims of violence, including unaccompanied minors and front-line health-care workers; detainees; and many more. The psychological effects of war, such as post-conflict trauma, have been shown to hinder peace and economic growth, sowing the seeds of further rounds of conflict and violence. ${ }^{38}$

\section{Challenges to humanitarian response}

\section{External pressures}

While the number and complexity of simultaneous conflict-driven crises around the world today has produced humanitarian needs on an epic (albeit hard to quantify) scale, the gap between those needs and the ability of international humanitarian actors to address them appears greater than at any other time in recent history. ${ }^{39}$

Just as it has come to define many of the key features of contemporary warfare, the Syrian conflict, in all its complexity, also encapsulates many of the

36 UNICEF and UN Special Representative for Children and Armed Conflict, "More Brutal and Intense Conflicts Leave Children Increasingly at Risk of Recruitment”, 12 February 2015, available at: www. unicef.org/media/media_79775.html.

37 Ibid.

38 See Alex Whiting, "Post-War Trauma Endangers Peacebuilding, Economic Growth - Experts", Thomson Reuters Foundation, 6 October 2015, available at: www.trust.org/item/20151006230243-is1tu/.

39 While this article outlines various reasons for this gap, humanitarian financing is one of the more quantifiable ones: see High Level Panel on Humanitarian Financing Report to the Secretary General, Too Important to Fail-Addressing the Humanitarian Financing Gap, December 2015, available at: http://reliefweb.int/report/world/high-level-panel-humanitarian-financing-report-secretary-general-tooimportant-fail, which states that while in 2015 the amount of humanitarian assistance worldwide was 12 times greater than in 2000, "never before has generosity been so insufficient" (p. v). 
reasons for this gap. The main reason is the politicization of aid, which is the single biggest threat to the ability of humanitarian organizations such as the ICRC to reach people in need of protection and assistance through an impartial, neutral and independent approach, in Syria as in other parts of the world. ${ }^{40}$

We have already seen that the rules of IHL requiring military forces and armed groups to facilitate the delivery of humanitarian relief supplies, and to respect medical neutrality so that all those needing medical treatment may receive it, are frequently ignored. Increasingly assertive States tend to insist on their own definition or understanding of "humanitarian assistance" - for example, restricting it to emergency relief - or impose administrative obstacles in order to hinder humanitarian assistance to contested parts of the country. Some even consider a neutral and independent approach as a challenge to their sovereignty. Partly as a result of this, some host States are increasingly favouring local responses over international ones, which is accelerating the decentralization and fragmentation of humanitarian response in general. The increasing empowerment of local actors, though broadly seen as a positive and necessary development, nevertheless poses particular challenges to international humanitarian actors in conflict settings (these are considered separately in the section "Localization of Aid: The Future of Humanitarian Action?", below).

At the same time, a sometimes bewildering array of non-State armed groups may be dismissive of both IHL and "traditional" (i.e., Western) humanitarian norms and practices, rejecting what they see as the imposition of Western values and therefore refusing access and failing to provide security. The difficulty of engaging with such groups-especially those which glorify atrocities - poses a particular challenge for organizations, like the ICRC, working in the field of protection. The designation of certain non-State armed groups as "terrorist" - effectively criminalizing principled humanitarian action in those contexts - only adds to this challenge.

The use of humanitarian aid as a tool for conflict management and counterinsurgency strategies - where the political, military and humanitarian agendas of key international players may be hard to distinguish-further jeopardizes perceptions of a principled approach and ultimately hinders the ability of organizations to gain impartial humanitarian access to people on both sides of a conflict. This has been the case in practically every context where international military intervention has been authorized in recent times (be it through UN Security Council resolutions invoking the "responsibility to protect" 41 or through other means), including Syria, Yemen, Libya, Iraq and Afghanistan (in the latter,

40 The humanitarian action of the Red Cross/Red Crescent Movement is specifically based on seven Fundamental Principles, namely humanity, impartiality, neutrality, independence, voluntary service, unity and universality. For further information, see: www.icrc.org/eng/resources/documents/misc/ fundamental-principles-commentary-010179.htm. See also statement by Taderatu Konoe and Peter Maurer, "Fundamental Principles: Reaffirming our Humanity, Reasserting our Neutrality and Impartiality", 8 October 2015, available at: www.icrc.org/en/document/50th-anniversary-fundamentalprinciples-reaffirming-our-humanity-reasserting-our-neutrality.

41 For information on the concept of "responsibility to protect" or R2P, see: www.responsibilitytoprotect.org. 
humanitarian aid was overtly used to "win hearts and minds" through means such as the NATO-led Provincial Reconstruction Teams).

Just as the "counterterrorism" strategies adopted particularly in the wake of the 9/11 attacks have impacted on the acceptance and reputation of humanitarian actors who might be perceived to be associated with them, so too has the "counter violent extremism" narrative that has gained momentum in recent years. Its "soft", prevention-oriented focus also raises a number of protection concerns, such as "de-radicalization" programmes inside prisons and more broadly by contributing to the legitimization of restrictive measures that may be difficult to monitor and safeguard against.

A diverse range of emerging actors claiming to deliver "humanitarian assistance" - when it is in fact relief assistance that is underpinned by political, military or economic objectives - further contributes to the blurring of agendas. The NGO Spirit of America, which in the words of advisory board member General (Rtd) Stanley McChrystal is a "philanthropic rapid response team providing humanitarian and economic assistance in support of our nation's interests", ${ }^{42}$ is just one example - projects include the provision of (non-lethal) equipment to a unit of the Nigerian Army fighting Boko Haram, and medical equipment to Ukrainian soldiers being trained by the US Army. ${ }^{43}$ Other examples abound, including private sector actors, faith-based organizations and civil society organizations responding in a broad range of humanitarian crises around the world.

The challenge in an increasingly crowded environment of new actors is to clearly distinguish and separate principled humanitarian action from pure relief assistance, and to be unequivocal that "humanitarian assistance" must at the very least be based on the principles of humanity and impartiality, regardless of the mandate or approach of the particular actor.

All of this is subsumed into the single most critical issue for humanitarian organizations working in the most difficult conflict situations (in places like Syria and Yemen today), which is to gain greater acceptance, access and proximity to the people directly affected, on both sides of the front lines. Lack of security is clearly a major constraint. National Societies have suffered a particularly high death toll of staff members and volunteers: in Syria, for example, by the end of 2015, a total of fifty staff members from the Syrian Arab Red Crescent and eight from the Palestine Red Crescent had been killed while carrying out humanitarian activities since the conflict began in March 2011. In Yemen, two ICRC staff members were killed in September 2015 and at least six Yemeni Red Crescent volunteers lost their lives between April and September of that year. Another ICRC staff member was killed in Mali in March 2015. Others still have been injured in attacks or taken hostage. 


\section{Internal constraints}

There are other, largely self-imposed reasons why very few humanitarian organizations are able to operate effectively in today's conflict zones. A key factor is that humanitarian agencies are increasingly outsourcing their response - and the risk that goes with it - to local implementers, resorting to "bunkerization" and remote management and retaining little or no control over how and where aid is distributed and no proximity to the people they are trying to help. ${ }^{44}$ The "do no harm" principle ${ }^{45}$ espoused by humanitarian actors in the past has, it seems, been replaced by one of "take no risk". One consequence is that the impartiality and relevance of the humanitarian response are jeopardized, especially where any credible perspective of the real needs and resilience of affected communities is lost.

MSF, in a 2014 report, ${ }^{46}$ pinpoints some of the key internal deficiencies in the international humanitarian aid "system" as a whole. Slow, inefficient and ineffective humanitarian response in conflict zones is attributed largely to the increasing absence of UN agencies and international NGOs from field locations, with international staff withdrawing and programmes being suspended just as needs become most acute. Little effort is made to reach people in remote, difficult areas. The trends of risk aversion and outsourcing mean that many humanitarian actors are effectively technical experts, intermediaries or donors rather than field actors, according to the report. The UN comes in for particularly tough criticism for being largely inflexible and ineffective in hotspots. The current UN system is said to hinder good decision-making especially in displacement crises where a number of UN agencies have a responsibility to respond. The report further contends that while largely bureaucratic international NGOs may profile themselves as emergency responders, they often lack the technical or human capacity to respond quickly and effectively. Often implementers for the UN, they are largely dependent on the geopolitical interests in play. Overall, the massive growth of the humanitarian sector in recent years has generally not been matched by improved performance.

Then, of course, comes the issue of money. Shortfalls in humanitarian funding as well as the systems by which it is disbursed are clearly factors contributing to the overall paucity of effective humanitarian response in today's conflict-driven crises (albeit not the only ones, as some actors might like to pretend. Large-scale funding appeals should-generally-be viewed with the caveat that there is in fact no objective or reliable measurement of global

44 Sarah Collinson and Mark Duffield, Paradoxes of Presence: Risk Management and Aid Culture in Challenging Environments, Humanitarian Policy Group (HPG), Overseas Development Institute (ODI), London, March 2013, available at: www.odi.org/publications/7514-risk-humanitarian-remotemanagement.

45 See Mary B. Anderson, Do No Harm: How Aid Can Support Peace - Or War, Lynne Rienner, Boulder, CO, 1999.

46 MSF, Where is Everyone? Responding to Emergencies in the Most Difficult Places, London, July 2014, available at: www.msf.org.uk/msf-report-where-everyone-responding-emergencies-most-difficult-places. 
humanitarian needs, due partly to lack of data, partly to imprecise and sometimes competing needs assessments, and partly to the complex, chronic nature of crises. Neither does the scale of an appeal necessarily match the available capacity to deliver services).

Still, funding figures tell their own story. Considering only the Syrian conflict with its regional repercussions, the resources required to even try to address this crisis are vast: the $\$ 3.8$ billion pledged by donors in Kuwait in March 2015 was still less than half of what the UN alone requested for the year to cope with the ever-growing needs inside Syria and its refugee-hosting neighbours. ${ }^{47}$ Critical funding shortages have forced the World Food Programme (WFP), for example, to reduce the level of assistance it provides to almost 1.3 million vulnerable Syrian refugees in the region: with the value of food vouchers reduced, most are now living on around 50 cents a day. Inside Syria, WFP says it received only a fraction of its funding requirements in 2015; this has resulted in a significant decrease in the size of food rations, meaning that families have to eat smaller meals, less frequently. ${ }^{48}$

Globally, as of November 2015, there was a $\$ 10.4$ billion shortfall in the amount requested in the UN's emergency appeals to tackle competing humanitarian crises around the world. ${ }^{49}$ Even appeals for "high-profile" conflicts such as Yemen were less than $50 \%$ funded, while for places like Djibouti, which is struggling to cope with the influx of Yemeni and Somali refugees, the figures were much lower still (a mere 15\% of requested funds for Djibouti were met). And as more crises drag on for longer periods of time, the gap between available funding and humanitarian needs can reasonably be expected to grow.

At the same time, "non-traditional" or informal funding systems are on the increase, although these are hard to quantify as they do not participate in global reporting systems. They include "emerging" State donors (such as China, India and various Gulf States) which are largely outside the Organisation for Economic Cooperation and Development's Development Assistance Committee and independent of the Good Humanitarian Donorship Initiative ${ }^{50}$ (and which tend to channel funds to neighbouring host States, preferring bilateral aid to multilateral mechanisms), as well as increasing numbers of non-governmental donors, including from the private sector and diasporas (in the form of remittances). As humanitarian needs continue to grow and the budgets of many traditional donor governments become more restricted, humanitarian organizations will need to become increasingly innovative in finding diverse new funding sources.

Moreover, traditional UN-centric donor funding systems are very well documented as being slow, inflexible, inefficient and often ineffective. ${ }^{51}$ NGOs in

47 OCHA, "Syria: UN and Partners Launch Major Appeal for 2015”, 18 December 2014, available at: www. unocha.org/top-stories/all-stories/syria-un-and-partners-launch-major-appeal-2015.

48 See: www.wfp.org/emergencies/syria.

49 See OCHA Financial Tracking Service, available at: https://fts.unocha.org/.

50 See: www.ghdinitiative.org.

51 For an overview and literature review, see Global Humanitarian Assistance/Development Initiatives, Think Piece: Humanitarian Financing, 2015, available at: www.globalhumanitarianassistance.org/report/ think-piece-humanitarian-financing. 
particular have long voiced concerns that UN-managed multilateral funding mechanisms (such as the Central Emergency Response Fund and pooled funding mechanisms) tend to hinder the delivery of emergency assistance to those in need, and that the proportion of direct bilateral aid from donors to front-line delivery agencies has decreased, thereby reducing the speed, timeliness and predictability of funding. Save the Children, for example, recently called for a greater proportion of funding to go to agencies directly involved in delivering aid (with an emphasis on non-UN and local actors) rather than UN agencies who subcontract to operational partners, thus reducing "double-handling" of humanitarian funds and improving efficiency on the ground. It also urged "[m]ore inventiveness in acquiring humanitarian funding by tapping the tens of billions from the corporate sector and from very wealthy individuals". 52

In a global environment of mainly protracted or recurrent conflicts and chronic humanitarian needs - where a vicious circle of conflict, poverty and weak governance in fragile States is easily perpetuated - a critical challenge is to "find a way to break down financial and institutional silos and work towards plans that make all resources count for crisis-affected people". 53 While the remit of humanitarian response is being stretched ever wider, the rigidly separate mechanisms in place for humanitarian funding and development assistancedespite all the rhetoric around "early recovery" in recent years - are not suited to today's realities. Reform of these mechanisms towards a more holistic approach is crucial; so too is the need to better harmonize resource flows from different sources and from different communities, be they national or international, public or private.

Closely connected to this, there is an increasing focus on the need to boost the resilience of communities affected by multiple crises around the world in order to save lives but also to reduce the overall cost of humanitarian assistance and disaster recovery. ${ }^{54}$ While resilience-building is rooted in disaster preparedness, the concept is gaining ground in protracted armed conflicts too. Speaking at the Resilience Development Forum in Jordan in November 2015, Helen Clark, head of the United Nations Development Programme (UNDP), emphasized the critical importance of resilience-based development to the international response to the crisis in Syria and its regional neighbours, stressing that " $[\mathrm{r}]$ esilience-building requires greater and more-predictable investments and we must pursue more practical, novel and innovative funding modalities and instrument $[\mathrm{s}]$ beyond existing classifications of international aid." ${ }^{55}$

52 See: www.savethechildren.net/article/humanitarian-system-urgently-needs-reform-save-more-lives-warnssave-children-world.

53 Global Humanitarian Assistance/Development Initiatives, above note 51.

54 El-hadj As Sy, quoted in Kieran Guilbert, "Boost Resilience to Save Lives in West Africa - Red Cross Head", Thomson Reuters Foundation, November 2015, available at: www.trust.org/item/ 20151110203218-fss2n/.

55 UNDP, "UN Development Chief: Resilience Critical to More Effective Syria Response”, November 2015, available at: www.undp.org/content/undp/en/home/presscenter/pressreleases/2015/11/10/un-developmentchief-resilience-critical-to-more-effective-syria-response.html. 
The issue can nevertheless be sensitive in armed conflicts, with a need for caution that building the resilience of conflict-affected people and communities in terms of their economic security, disease prevention and psychosocial recovery does not become blurred with the intolerable idea of trying to make them resilient to abuses and repeated violations of IHL.

A broader problem with humanitarian funding is that it is generally not targeted impartially, according to need. This is partly because of the aforementioned lack of an accurate picture of global needs, and also because global funding allocations still tend to favour responses in geographically or politically strategic countries over neglected or protracted crises. ${ }^{56}$ And while the information revolution and innovative uses of communication technologies are increasingly empowering crisis-affected communities to articulate their needs and how they should best be addressed (and by whom), the international humanitarian system as such is still struggling to fully embrace this fundamental power shift and the vision of a different future that comes with it (see section "Localization of Aid: The Future of Humanitarian Action?", below).

\section{Evolution of humanitarian action in a changing world: A short history}

The gap between today's overwhelming humanitarian needs and the constraints on international humanitarian actors' efforts to address them is seen by some as unbridgeable, pushing organizations to "breaking point". In 2014, then head of the UNHCR António Guterres said that the scale of forced displacement caused by conflicts around the world had created "a situation where humanitarian needs are growing exponentially and the capacity to respond is not able to match", and that "the humanitarian community [had] reached its limit". ${ }^{57}$ Jan Egeland, former UN emergency relief coordinator and now head of the Norwegian Refugee Council, despaired that "the system is totally broken". ${ }^{58}$

With its capacity overstretched and its acceptance and relevance challenged as never before - particularly by non-Western donors and recipient States, emerging non-State groups and increasingly by local actors and beneficiaries themselves - the international humanitarian system is undoubtedly facing a critical test. Indeed, the very concept of one neatly drawn, interconnected "system" seems outdated in what has become a much wider "ecosystem" of diverse actors within the global

56 Ingrid Macdonald and Angela Valenza, Tools for the Job: Supporting Principled Humanitarian Aid, Norwegian Refugee Council and HPG, ODI, London, October 2012, available at: www.odi.org/node/ 17771.

57 “Aid Groups 'Can’t Cope' with Spate of Global Conflicts”, Independent.ie, 5 November 2014, available at: www.independent.ie/world-news/middle-east/aid-groups-cant-cope-with-spate-of-global-conflicts30720065.html.

58 Quoted in Lyse Doucet, “A Broken System for a Broken People”, BBC News, 6 January 2015, available at: www.bbc.com/news/world-middle-east-30699835. 
humanitarian landscape. ${ }^{59}$ At best, there may be multiple "systems" - working on local, national and international levels - with varying degrees of organization, different approaches and different goals. This broad humanitarian landscape and all of its features are evolving constantly, shaped by the increasing complexities of the causes and consequences of war, violence and disasters, and will inevitably assume quite a different shape in the years to come (this will be discussed further in the following section).

Yet in many ways, this has always been the case. While the humanitarian gesture can be traced back centuries in different parts of the world - particularly in religious belief and in the articulation of the laws of war- "modern" international humanitarian action has undergone major transformations since its broad origins in the nineteenth century and the largely European (and American) experience of war. ${ }^{60}$ There does now appear to be a growing awareness that historical analysis - which needs to go beyond just the Westerncentric experience-can inform reflection on the current challenges facing international humanitarian action and better preparation for the changes that may take place in the future. ${ }^{61}$ While it is beyond the scope of this article to offer such analysis, even a brief and partial scan of the evolution of international humanitarian action over the last century and a half helps to frame the current challenges and put them into a certain perspective.

More than fifty years before the First World War, the creation of the ICRC in 1863 was undoubtedly pivotal in the birth of modern humanitarian action. Witnessing the carnage on the battlefield at Solferino four years earlier, Henry Dunant clearly recognized the need not only for impartial medical services that would treat wounded soldiers on both sides of the front line, but also for organized humanitarian relief and trained volunteers, as well as the importance of international cooperation to achieve this. Dunant and four fellow Geneva citizens went on to establish the ICRC and draw up the First Geneva Convention of 1864, aimed at protecting sick and wounded soldiers and those caring for them from attack. The subsequent formation of National Red Cross and Red Crescent Societies saw the development of concerted and coordinated humanitarian action for a successively broader range of victims of war, on the basis of a growing body of IHL. The concept of neutral, impartial and independent humanitarian action carried out by workers under the protection of a distinctive emblem continues to be at the heart of the Red Cross and Red Crescent Movement - now comprising the ICRC, the International Federation of Red Cross and Red Crescent Societies (IFRC) and 190 individual National Societies.

59 See Randolph Kent, Justin Armstrong and Alice Obrecht, The Future of NGOs in the Humanitarian Sector, Humanitarian Futures Programme, Kings College London, August 2013, available at: www. humanitarianfutures.org/events/the-future-of-humanitarian-ngos/.

60 Eleanor Davey, John Borton and Matthew Foley, A History of the Humanitarian System: Western Origins and Foundations, HPG, ODI, London, 2013, p 5.

61 See ODI project on "A Global History of Modern Humanitarian Action", available at: www.odi.org/ projects/2547-global-history-modern-humanitarian-action-moving-forward-hpg. 
Dunant was also astute enough to foretell changes in the nature of warfare. "If the new and frightful weapons of destruction which are now at the disposal of nations seem destined to abridge the duration of future wars," he wrote in $A$ Memory of Solferino, "it appears likely, on the other hand, that future battles will only become more and more murderous." Less than a decade later, the St. Petersburg Declaration was the first formal agreement prohibiting the use of certain weapons in war.

At the same time, humanitarian action was being shaped by imperial expansion and colonial power structures which would stay intact until the second half of the twentieth century. Impartiality was lost in an enterprise that prioritized the health needs of Europeans in the colonies. Christian missionaries played an important part in expanding this effort to indigenous populations through religious conversion. ${ }^{62}$

The outbreak of the First World War in 1914 posed an unprecedented challenge to humanitarian response, causing more death and destruction than any previous conflict. New weapons and methods of warfare were introduced, including chemical weapons and long-range bombardment. Ten million peopleservicemen and civilians - were captured and sent to detention camps. The ICRC, supported largely by volunteers of the thirty-eight National Societies in existence at the time (the ICRC had only twelve paid staff at the start of the war $^{63}$ ), expanded its traditional front-line work with wounded or sick soldiers to include working on behalf of prisoners of war, protecting and assisting civilians (especially those living in enemy-occupied territory), campaigning against the use of chemical weapons, and in the immediate post-war period, dealing with the consequences of civil war in the wake of the Russian and Hungarian revolutions.

The aftermath of the Great War - with its massive challenges around food security, outbreaks of disease (notably the flu epidemic of 1918-19 that killed an estimated 50 million people), mass displacement and statelessness-saw the increasing international coordination and institutionalization of humanitarian practice. National Societies came together under the League of Red Cross Societies in 1919, the predecessor of the IFRC. The following year, the Genevabased League of Nations was born of US president Woodrow Wilson's vision of international reform - the first international body whose sole purpose was to maintain world peace. While the League's inherent weaknesses foretold its ultimate failure on a political level, it did score some successes on other levels, notably in the creation of the Nansen International Office for Refugees, the predecessor of the UNHCR, under Fridtjof Nansen. Another notable development around this time was the establishment of what has been described as the "first recognisable trans-national humanitarian NGO"64, the Save the

62 Michael Barnett and Thomas G. Weiss, "Humanitarianism: A Brief History of the Present", in M. Barnett and T. G. Weiss (eds), Humanitarianism: Politics, Power, Ethics, Cornell University Press, Ithaca, NY, 2008.

63 David Forsythe, The Humanitarians: The International Committee of the Red Cross, Cambridge University Press, Cambridge, 2005.

64 Peter Walker and Daniel G. Maxwell, Shaping the Humanitarian World, Routledge, London, 2009 , p. 25. 
Children Fund, which quickly expanded from its British base to sections in various countries.

The Second World War marked a new turning point. Trench warfare was overtaken by mechanized warfare, and massive air strikes targeted primarily civilian populations. Civilians were also the main targets of ruthless occupation policies first by Nazi Germany and its allies and later by conquering armies. Governments and private voluntary agencies led relief efforts. Yet the scale of humanitarian needs was unprecedented - on five continents simultaneously - and far surpassed the capacity of available response resources, both human and financial. The ICRC, for its part, further expanded its activities and worked increasingly to meet the needs of civilians, including famine relief in places like the Greek Aegean Islands. However, the ICRC's notorious failure to denounce Nazi atrocities, and to work on behalf of civilians in the occupied areas or those deported to death camps, "remains synonymous with tragedy in the institution's memory". 65

The atomic bombing of Hiroshima and Nagasaki in August 1945 precipitated the end of the war and a new era in international relations: one dominated by tensions between two blocs and the threat of nuclear war. The demise of the League of Nations and the establishment of the UN in 1945 was followed by the creation of specialized agencies such as UNICEF, the UN Food and Agriculture Organization (FAO), the World Health Organization and the UNHCR in 1951, and ten years later, the FAO-run World Food Programme, born of the US "food for peace" policy that was driven by surplus agricultural production. Also in the post-war period, a number of important normative and legal frameworks were established, including the Universal Declaration of Human Rights (1948), the Convention on the Prevention and Punishment of Genocide (1948) and the 1949 Geneva Conventions, which updated and expanded the laws of war.

During the Cold War, the process of decolonization and the emergence of the "third world" shifted the focus of international humanitarian action from European relief and reconstruction to helping the hungry and needy in newly independent, "less developed countries". As Michael Barnett notes, "humanitarianism had gone global". ${ }^{66}$ NGOs that had been established during the Second World War - such as Oxfam, CARE, Catholic Relief Services and many others - dramatically expanded their budgets and the scope of their activities, while many new ones were created, often with extremely close ties to the Cold War policies and priorities of their home governments. ${ }^{67}$ At the same time, the international development discourse gathered momentum, with many new States joining the UN and making their demands heard on a global platform.

The Nigeria-Biafra civil war and the ensuing famine in the late 1960s set a critical test for international humanitarian action - one which was largely failed by

65 See ICRC, “1939-1945: Overview”, available at: www.icrc.org/eng/who-we-are/history/second-world-war/ overview-2-world-war.htm.

66 Michael Barnett, Empire of Humanity: A History of Humanitarianism, Cornell University Press, Ithaca, NY, 2011.

67 E. Davey, J. Borton and M. Foley, above note 60. 
all concerned (not least the ICRC, whose massive yet muddled relief effort was aborted when one of its planes was shot down by the Nigerian government, and whose neutrality was seen by some as an excuse for inaction or worse). The crisis caused a serious split in the international humanitarian community and gave birth to a new generation of rights-based humanitarianism based on "bearing witness" and the principles of denunciation and the right to intervention, of which MSF is the best-known protagonist (although it later became clear that the partisanship of NGOs vis-à-vis the Biafran cause had been overtly instrumentalized by the secessionists, prolonging the conflict and causing more suffering). In recent years, however, the ICRC and MSF have become much closer in terms of their approach - essentially a "Dunantist" one - in difficult situations of armed conflict, where they are often among the very few international actors who are effective front-line responders (this will be discussed in more detail in the following section).

Famine in Africa became a major defining factor for international humanitarian action in the 1970s and 1980s, with the Ethiopian famine of 198485 coming to symbolize the prevailing media-driven mobilization, lack of coordination and ultimately manipulation of relief aid. But by the time the Cold War ended in the early 1990s, there was an unprecedented number of mostly non-international armed conflicts in different parts of the world, ${ }^{68}$ many of which came to be known as "complex emergencies" due to the multiplicity of their causes, the diversity of actors involved and the wide range of humanitarian consequences requiring a multisectoral response.

At the same time, there was a rapid increase in the number of UN peacekeeping missions around the world, with the Security Council authorizing a total of twenty new operations between 1989 and 1994, raising the number of peacekeepers from 11,000 to 75,000 (the first of an increasing number of operations explicitly mandated to protect civilians only came in 1999: UNAMSIL in Sierra Leone). The 1990s were however marked by the catastrophic failures of UN peacekeeping in the Somalia conflict, the Rwandan genocide and the Balkans - and by the overt politicization and instrumentalization of humanitarian response (with the collusion of some humanitarian actors themselves). Perceptions and respect for international humanitarian action as a whole had sunk to a new low. ${ }^{69}$

The international humanitarian community reacted to the criticisms and perceived shortcomings with much debate and a number of initiatives in the 1990s and beyond, such as various codes of conduct (which have proliferated since the creation of the 1994 Red Cross/NGO Code of Conduct), including the Sphere Project Minimum Standards in 1997 and numerous country-specific codes; the Good Humanitarian Donorship initiative in 2003; and the UN-led Humanitarian Response Review in 2005, a landmark initiative aimed at addressing perceived weaknesses, particularly in coordination, leadership and 
funding. The resulting reforms created, inter alia, the "cluster system" of coordination and a number of new funding mechanisms. Sorely tested by both natural disasters (such as the 2010 earthquake in Haiti) and the increasing scale and complexity of conflict-driven crises, the effectiveness and ultimately the future of these structures and mechanisms is once again under debate. ${ }^{70}$

Indeed, it is hard to think of a time in recent decades when international humanitarian action was not in crisis. The 9/11 attacks and the humanitarian consequences of the so-called "global war on terror" triggered another turning point, with international relations becoming polarized and the political, military and humanitarian objectives of Western donor governments becoming increasingly indistinct. US-led military interventions in Afghanistan and Iraq posed major challenges to upholding humanitarian principles in these contexts (as discussed earlier in this article). The 2003 bombing of UN headquarters and ICRC offices in Baghdad marked a low point in terms of perceptions and acceptance of humanitarian action in the early post-9/11 era.

Now, with the massive humanitarian fallout from the Syrian conflict and the many other concurrent crises around the world, familiar criticisms of an inept and broken humanitarian response system are resurging again. ${ }^{71}$ History shows that many of the challenges are also familiar: massive humanitarian needs outstripping available response capacity and resources; the politicization of humanitarian aid and its use as a vehicle for other agendas (including the deliberate blurring of terrorism and war); the role of the media; the erosion of humanitarian principles; poor coordination and leadership among humanitarian organizations; inefficient and ineffective funding mechanisms; and the questionable relevance and effectiveness of international humanitarian response. And, as in the past, change from within - through structural and mechanical reform - will only achieve so much.

All the forces at play in today's turbulent humanitarian landscape are already changing the shape of international humanitarian action, whether the actors like it or not. For these actors, the choice "is not about whether to like or dislike the world that is emerging in the second decade of the 21st Century, the choice is about adaptation, collaboration and re-discovering their role, or not". ${ }^{72}$

\section{Localization of aid: The future of humanitarian action?}

The future shape of humanitarian action will be determined by various factors, including the increasing assertiveness of States and insistence on sovereignty, the politicization of aid, the proliferation and diversification of new actors, security

70 See Paul Knox Clark and Leah Campbell, Exploring Coordination in Humanitarian Clusters, ALNAP, London, June 2015.

71 MSF, above note 46. See also Paul Currion, “The Humanitarian Future”, September 2014, available at: https://aeon.co/essays/humanitarianism-is-broken-but-it-can-be-fixed.

72 R. Kent, J. Armstrong and A. Obrecht, above note 59. While the authors refer to NGOs, their assertion is relevant to all parts of the humanitarian "system". 
issues, new technologies and the drive towards a common approach to emergency relief and development. While it is beyond the scope of this article to re-examine these issues, on which there is already a wealth of literature, ${ }^{73}$ one issue in particular that has been increasingly central to debates on humanitarian reform and the future of humanitarian action will be looked at more closely here, namely the "localization" of aid.

The debate around this issue - in terms of the role of local humanitarian actors and that of crisis-affected people (which may naturally overlap) - has been dominant in the various reform-oriented UN initiatives currently under way, not least the process around the Sustainable Development Goals (SDGs) and the 2016 World Humanitarian Summit (WHS). The latter aims to "put people at the heart of humanitarian action", building on the ethos of the SDGs, through which world leaders "have pledged to leave no-one behind". ${ }^{74}$ The global consultations ahead of the WHS emphasized that "affected communities, their organizations and their communities should be recognized as the primary agents of their preparedness, response and recovery", that "all humanitarian actors, both national and international, should complement local coping and protection strategies wherever possible", and that "people affected by crises should be enabled to exercise greater voice and choice in humanitarian action". ${ }^{75}$ According to the IFRC, local actors are the "key to humanitarian effectiveness", and "there is a growing feeling that strengthening the role of local actors may finally help to redress some of the perennial challenges of humanitarian aid, such as shrinking access, fragmentation and incoherency in operations, and the gaps between response, recovery and development". ${ }^{76}$

In a similar vein, the Future Humanitarian Financing Initiative ${ }^{77}$ envisages a future in which "much of the cost of providing humanitarian assistance will be borne by local and domestic actors, including affected governments, communities, civil society groups, businesses and regional organizations", and where rising and emerging donors will challenge and reshape modes of assistance, supporting the rise of new responding actors.

73 See, for example, the collection of articles in the thematic issue on "The Future of Humanitarian Action", International Review of the Red Cross, Vol. 93, No. 884, 2011, available at: www.icrc.org/en/internationalreview/future-humanitarian-action. See also Justin Armstrong et al., The Future of Humanitarian Security in Fragile Contexts, Humanitarian Futures Programme, April 2014, available at: www.humanitarianfutures.org/ publications/2507/; IFRC, World Disasters Report 2013: Technology and the Future of Humanitarian Action, 2013, available at: www.ifrc.org/en/publications-and-reports/world-disasters-report/world-disasters-report2013/.

742030 Agenda for Sustainable Development, available at: https://sustainabledevelopment.un.org/post2015/ transformingourworld.

75 WHS, Restoring Humanity: Global Voices Calling for Action (Synthesis Report of the Consultation Process), October 2015, p. 2, available at: www.worldhumanitariansummit.org/whs_global/synthesisreport.

76 IFRC, World Disasters Report 2015, September 2015, p. 11, available at: http://ifrc-media.org/interactive/ world-disasters-report-2015/.

77 Catholic Agency for Overseas Development et al., Future Humanitarian Financing: Looking Beyond the Crisis, May 2015, available at: http://reliefweb.int/report/world/future-humanitarian-financing-lookingbeyond-crisis. (This initiative is linked to the IASC Task Team on Humanitarian Financing and ultimately to the UN High Level Panel on Humanitarian Financing.) 
More broadly, in view of the widely held belief that "the global South remains one of the defining terrains for humanitarian action in the twenty-first century", ${ }^{78}$ how international humanitarian actors interrelate with predominantly non-Western, "local" actors, and with crisis-affected populations themselves, may reasonably be seen as critical to their future.

Discussions about the importance of "localizing aid" - closely connected to the concepts of participation of crisis-affected people, capacity-building and accountability - are of course nothing new, growing out of development theory and practice in the 1980s and 1990s. This was recognized as important not only as a matter of dignity for people affected by crisis, but to make response as relevant and effective as possible, mainly in the context of disaster risk reduction, preparedness and recovery. Local aid actors, in all their diversity, ${ }^{79}$ are invariably the first to respond in emergencies: their proximity and first-hand knowledge and understanding of their own contexts cannot be matched. The increasing recognition of the importance of building the resilience of crisis-affected people and communities - in terms of disaster risk reduction and preparedness but also in situations of protracted conflict - puts a premium on the role of local actors.

While the concept of engaging with crisis-affected people has been institutionalized in countless resolutions, aid policies, codes of conduct and standards, practice on the ground has been inconsistent at best, with generally more rhetorical than real results. This has been partly due to some genuine constraints, particularly in complex and fragmented situations of armed conflict where access and actual presence are problematic. It has also been due in some cases to the perceived condescension of humanitarian actors, whose efforts to engage beneficiaries have been dismissed as donor-appeasing tokenism, and to services that lack quality and relevance. ${ }^{80}$

In situations of armed conflict, the localization agenda brings with it some real concerns and a number of broad assumptions, principally about aid being delivered in accordance with humanitarian principles and a weakening of the protection aspect of humanitarian response. Local actors may have additional political goals - but then, so too may multi-mandated international organizations that are part of a "coherence" agenda (as in UN integrated missions, for example). Especially in the case of new, "untested" local actors (regardless of their knowledge, capacity and networks), international agencies tend to be wary not only of their adherence to humanitarian principles, but generally of their

78 E. Davey, J. Borton and M. Foley, above note 60.

79 There is no universally accepted definition of what "local" means in this context. One suggested differentiation is that " $[\mathrm{t}]$ raditional humanitarian actors are the networks of international and national organizations that deliver aid in accordance with core principles and are included in the formal humanitarian system. Local aid actors encompass charities, civil society groups, faith-based organizations, volunteer groups, private sector actors, communities and diaspora bodies involved in providing protection and assistance in ways that may not be explicitly aligned with core principles and/or outside of the formal humanitarian system." IFRC, above note 76, p. 152.

80 See Dayna Brown, Antonio Donini and Paul Knox Clarke, 29th ALNAP Annual Meeting: Engagement of Crisis-Affected People in Humanitarian Action, February 2014, available at: www.alnap.org/resource/ 10439.aspx. 
professionalism, transparency and accountability, and of their operational standards. Excessively rigid criteria for partnerships have certainly led to lost opportunities. ${ }^{81}$ At the same time, the general increase in remote management and "bunkerization" by international actors raises ethical questions about risk transfer to local implementing "partners".

Establishing solid, well-managed operational partnerships usually takes time and effort, building on mutual respect and real commitment. This can lead to operational delays, while genuine integrity and security management concerns must also be carefully managed. In the experience of the ICRC and National Societies, this initial investment pays off in successful operational partnerships once clear structures and processes are created, strengthening both partners' access and acceptance, enhancing their capacity and making assistance more relevant. $^{82}$

Although there is relatively little systematic research and literature on South-South humanitarian responses in conflict settings, ${ }^{83}$ even anecdotal evidence points to the growing role of local actors in some of the most challenging environments. In Syria, for example, where humanitarian access for international actors is particularly constrained, the Syrian Arab Red Crescent is a key actor (and the ICRC's main partner in the country), although it too faces enormous challenges, not least in terms of security, as discussed earlier in this article. Meanwhile, the "informal" system is growing exponentially. According to the UN Office for the Coordination of Humanitarian Affairs (OCHA), the number of diverse local NGOs providing different kinds of relief assistance in Syria - including a wide range of professional bodies, diaspora groups, faith-based groups and fighting groups or activists - increased from twelve at the start of the conflict to 600-700 in 2015, about a fifth of them based inside Syria. While many diaspora organizations started off in an ad hoc manner, the professionalism of their approach and their resources soon grew. ${ }^{84}$ In Somalia, to take just one other example, different types of commercial actors have played a significant role in meeting the relief needs of conflict-affected populations. ${ }^{85}$

The relationships and types of engagement between international and local actors in conflict settings - and between local actors themselves-are highly contextual and constantly shifting with the dynamics of the conflict itself. Yet, regardless of different terminologies of "engagement", "partnership", "cooperation" or "collaboration" - and despite the aspirational visions of the

81 IFRC, above note 76, p. 161.

82 ICRC, Guidelines for Effective National Society and ICRC Partnerships, internal document, revised ed., Geneva, 2012.

83 Julia Pacitto and Elena Fiddian-Qamiyeh, Writing the "Other" into Humanitarian Discourse: Framing Theory and Practice in South-South Responses to Forced Displacement, Research Paper No. 257, Refugee Studies Centre, University of Oxford, July 2013.

84 Eva Svoboda and Sara Pantuliano, International and Local/Diaspora Actors in the Syria Response, HPG, ODI, London, March 2015.

85 Rukhe Zehra Zahidi, Samuel Carpenter and Joanna Burke, Commercial-Humanitarian Engagement in the Horn of Africa Crisis: A Scoping Study of the Response in Kenya and Somalia, Humanitarian Futures Programme, Kings College London, London, 2012. 
localization of aid - the reality remains one of "unequal power relations ... between international and local relief actors". ${ }^{86}$ The WHS global consultations concede that "the current system remains largely closed, with poor connections to ... emerging donors and increased South-South cooperation, and to a widening array of actors". The system, it says, "is seen as outdated". 87 "While contributing to humanitarian action in immense ways, national/state institutions and local organizations have often been kept at arm's length by the international humanitarian community", says another study. ${ }^{88}$

This imbalance is starkly illustrated by global humanitarian funding patterns. According to Development Initiatives, between 2009 and 2013, local and national NGOs combined received a total of $\$ 212$ million $-1.6 \%$ of the total given directly to NGOs and $0.2 \%$ of the total international humanitarian response over the period.

The prevailing power imbalance in this domain is being met with growing impatience by some NGOs from the global South. At the WHS global consultations, held in Geneva in October 2015, there was heated debate about the issue, with some southern NGOs levelling accusations of "neo-colonial" behaviour. A leading voice was Degan Ali, executive director of African Development Solutions (Adeso), who told the meeting of government representatives, UN officials and humanitarians that "Southern NGOs are demanding accompaniment rather than direction. Prepare to be uncomfortable." 89 She laid out plans for the establishment of a southern NGO network, lobbying for a pooled fund managed by NGOs headquartered in the global South, and a target of $20 \%$ of all humanitarian funding to go directly to local organizations, among others. There was a dominant view that any attempt at humanitarian reform would have to address the "institutionalized discrimination" that currently exists. Although Southern NGOs might not yet present a united front, their power and momentum will only grow.

While some international NGOs reacted defensively, others conceded that "aid must be as local as possible, and as international as necessary. We in the INGO community are ready and prepared to be part of that change." ${ }^{\circ 0}$

Many would say there is no choice: international humanitarian organizations must accept change and adapt accordingly, which may entail accepting a smaller role. In 2015, the Geneva-based Steering Committee for Humanitarian Response, an alliance of major international humanitarian organizations (currently chaired by the ICRC), laid out a stark vision of where ongoing changes were leading, at least in "straightforward" crises where access is relatively unproblematic:

86 IFRC, above note 76, p. 159

87 WHS, above note 75 , p. 6.

88 Steven Zyck and Hanna Krebs, Localising Humanitarianism: Improving Effectiveness through Inclusive Action, HPG, ODI, London, July 2015, p. 1.

89 Quoted in Imogen Wall, "Gloves Off between Local and International NGOs”, IRIN, 22 October, available at: www.irinnews.org/report/102141/gloves-off-between-local-and-international-ngos.

90 Ian Ridley, Senior Director of World Vision, quoted in ibid. 
In just a few years from now, the face of international humanitarian action as we know it will be irrevocably transformed. People and communities affected by crisis-informed, connected and empowered through easy access to technology - will choose from increasingly diverse sources of aid, be they public or private, local or international, while the aid industry risks becoming precisely that: a large-scale business. The role of "traditional" humanitarian actors - beyond helping to facilitate this inexorable power shift-will be limited to pockets of "off grid" situations of protracted conflict and extreme violence, where access will be a prevailing challenge. ${ }^{91}$

There is undoubtedly some credence to this view. Brown and Donini assert that as people globally have better access to information and technology, crisis-affected communities are increasingly likely to demand higher levels of engagement in decisions that concern them, and demand increasing accountability from national authorities via the ballot box. While there "may well continue to be situations where national authorities or non-State actors are unwilling or unable to uphold humanitarian principles and where international humanitarian agencies will continue to play a key role, the tolerance for sub-par services and arrogant behaviour will diminish". ${ }^{22}$ They further contend that as middle-income countries develop their national capacity to prepare for and respond to crises, the role of international humanitarian agencies will inevitably change and become more advisory and less operational. Oxfam has likewise suggested that international NGOs will become "humanitarian brokers: facilitating, supporting, and bringing together local civil society", 93 and this role may also increase as more international actors resort to remote management.

Even in the "off grid" situations where international humanitarian actors may still play an important role, they will need to be ever more innovative to prove themselves as relevant and effective. This will mean different things to different actors. Better harnessing the enormous opportunities posed by new technologies, continuously looking for new ways to better communicate with and empower the people at the centre of humanitarian response, and connecting better to increasingly diverse stakeholders and potential partners - including from the private sector, civil society and the full range of "local" actors - will be increasingly common objectives in all environments.

More effective, and sincere, capacity-building of local humanitarian actors may be one factor in this adaptation. According to François Audet,

if the humanitarian movement is to maintain its purpose, preserve its value, and respond to criticism about the impact of its action ... international organizations need to rethink their actions and transform their management model from one of "delivering services" to one of "support and local

91 Yves Daccord, From "victims" to "consumers"?: changing perceptions of humanitarian aid beneficiaries, Humanitarian Practice Network, ODI, London, 2 March 2015.

92 D. Brown, A. Donini and P. Knox Clarke, above note 80, p. 16.

93 Edmund Cairns, Crises in a New World Order: Challenging the Humanitarian Project, Oxfam Briefing Paper No. 158, Oxfam International, February 2012, p. 3. 
capacity-building". This change implies that they should no longer be guided according to their own interests and capacities, but according to the interests and capacities of their Southern partners. ${ }^{94}$

For the ICRC - and others of the "Dunantist" humanitarian tradition, such as MSF, working in constrained and complex situations of armed conflict - this will mean working harder than ever to demonstrate the value and practical application of humanitarian principles by responding to actual needs, ensuring proximity to the people at the centre of the response, and engaging with all stakeholders. More broadly, collaboration in the development of innovative approaches to humanitarian action is one important factor. ${ }^{95}$ Principled yet pragmatic operational partnerships-primarily within the Red Cross and Red Crescent Movement, but also with certain UN agencies and non-governmental agencies, both international and national - are another.

In short, for all international humanitarian actors, this will include finally walking the talk about engaging and empowering beneficiaries-that is, increasingly ceding decision-making powers to those directly affected by crisis, and recalibrating the balance of power between international and local humanitarian actors.

\section{Conclusion}

The state of conflicts today - and the overall paucity of effective response to the overwhelming humanitarian needs they produce-has prompted critics from many quarters to declare the "end of humanitarianism", or more precisely, "the end of international humanitarian action". ${ }^{96}$ This article has sought to make the case that the question facing humanitarian action is less one of "make or break" than it is of accepting that the ever-shifting dynamics of war and violence, and all the geopolitical realities around them, will in any case naturally reshape the nature and form of humanitarian response. It also seeks to highlight some of the opportunities facing humanitarian actors in an increasingly diverse landscape.

A descriptive analysis of some of the key trends and features in today's conflict-driven crises, the impact these have on the needs, vulnerabilities and resilience of people affected by them, and the challenges that they, in turn, pose particularly to international humanitarian actors leads to a reasonable conclusion that the humanitarian system is, at best, facing a very serious test. As the Syrian

94 François Audet, "What Future Role for Local Organizations? A Reflection on the Need for Humanitarian Capacity Building”, International Review of the Red Cross, Vol. 93, No. 884, 2011, p. 1164.

95 See, for example, the various initiatives launched through the ICRC's "Global Partnerships for Humanitarian Impact and Innovation" platform, available at: http://blogs.icrc.org/gphi2/.

96 See, for example, Daniel Nelson, “Afghanistan: The End of Humanitarianism?”, One World News, 10 December 2012, available at: http://oneworld.org/2012/12/10/afghanistan-the-end-of-humanitarianism; Christopher J. Coyne, Doing Bad by Doing Good: Why Humanitarian Action Fails, Stanford University Press, Stanford, CA, 2013; Yves Daccord, “The End of Humanitarianism, Again?", Thomson Reuters Foundation, 2 December 2014, available at: http://news.trust.org//item/20141201075225-n0dsh/. 
armed conflict demonstrates, war is more complex ${ }^{97}$ and generally more protracted than ever before, and while the number of armed conflicts has decreased in recent years, the number of fatalities has nevertheless been rising, while other situations of violence have also been increasing. The number of concurrent, drawn-out crises around the world is producing humanitarian needs on an overwhelming scale. And the various parts of the international humanitarian system are beset by internal weaknesses and external challenges to such an extent that they are increasingly paralyzed, if not absent altogether, in conflict zones where the needs are greatest.

Looking back at the evolving humanitarian landscape of the past 150 years or so, it is clear that humanitarian response has always had to adapt - more or less successfully - to the changing realities confronting it, and the continuous challenges to its acceptance, relevance and effectiveness. The major landmarks of the twentieth century and beyond - the trauma of the two World Wars; decolonization and the wars of liberation; the polarization of the Cold War and the fragmentation caused by its end; the globalization of humanitarianism in the 1990s as non-international armed conflicts reached a peak; the post-9/11 era with its so-called "global war on terror" and more recently the rise of radical jihadism and the "counter violent extremism" narrative - have all set enormous challenges to the integrity and value of international humanitarian action, which has naturally undergone transformative changes as a result.

Now, the evolution of the international environment towards a new multipolar order - with the rise of the "global South" and its challenge to the predominance of the "West" - is likewise reflected in the evolving paradigm of humanitarian aid, one which is again testing the acceptance and relevance of international organizations. In the face of increasing State-based assertions of sovereignty, and the overt politicization and militarization of aid, humanitarian response as such is likely to become increasingly diversified and fragmented among different actors, both local and international. Different types of aid will most likely coexist, including initiatives led by the private sector, deployment of military assets, bilateral State aid, UN-led integrated approaches, and neutral and impartial humanitarian action. Increasingly diverse, "non-traditional" donors will likewise impose their own agenda, challenging the monopoly of Western States on humanitarian funding. And in such a competitive humanitarian arena, recipients of humanitarian aid may increasingly "decide who they want to help them, in what ways, and for how long". ${ }^{98}$ This would effectively increase the onus on providers of aid to prove themselves in terms of relevance, effectiveness and overall value - to donors, to the public at large, and most particularly to crisisaffected people themselves.

The "system" as such is not deaf to criticism: various efforts have been made over the past two decades or so to rectify some of the more glaring

97 For an analysis of modern-day "complex" wars (as opposed to "conventional" wars), see Martin van Creveld, "War in Complex Environments: The Technological Dimension", PRISM, Vol. 1, No. 3, 2010.

98 D. Brown, A. Donini and P. Knox Clarke, above note 80, p. 25 
weaknesses, albeit with limited success. Many of the codes and standards formulated in the 1990s were, in effect, simply reaffirmations of humanitarian principles and statements of good intent that are hard if not impossible to monitor and enforce. UN structural reforms have also yielded mixed results, with the key areas of funding, coordination and leadership once again at the centre of debate. The UN-led World Humanitarian Summit in 2016-the culmination of a nearly three-year consultation process focusing on conflict, humanitarian effectiveness, reducing vulnerability and managing risk, and transformation through innovation - offers a new opportunity to improve aid delivery to those affected by crisis. ${ }^{99}$

However, while the perennial debate about the future of humanitarian action still revolves largely around money, principles and institutional reform, many see the crux of the matter to be a question of power - more precisely, how much of it international humanitarian organizations are willing to give up. The international humanitarian "system" is only one part of a much wider ecosystem of humanitarian response, parts of which have been largely marginalized but are now demanding fair recognition. As Paul Currion compellingly writes, "humanitarian organisations must become hubs, connecting individuals and communities to enable them to share knowledge and resources more freely, and using their position to embed humanitarian principles within their networks". ${ }^{100}$ These organizations must aim to create a "people's humanitarianism rather than the private club that exists now" and must seize the opportunities provided by new communication technologies towards this end. ${ }^{101}$

"Local" actors in all their diversity - including well-informed, tech-savvy and empowered beneficiaries themselves - will increasingly determine the type, source and duration of aid. The question is not about local replacing international actors - both have roles to play - but a better, fairer balance must be struck.

International humanitarian actors will continue to adapt to a changing world and redefine their role as they have in the past, not only because they must in order to stay relevant and continue to exist, but also as long as the fundamental desire and ambition to uphold human dignity even in the midst of armed conflict continues to be their main driving force. 